folk/ed. 2021; 27(2) $106 \mathrm{Ek}$

DOI: $10.22559 /$ folklor.1740

\title{
Erken Cumhuriyet Dönemi Kadın Dergilerinde Kadın İmajı: Ev Kadın Dergisi Örneği
}

\section{The Image of Women in Early Republican Era Womens Magazines: The Example of Ev Kadın Magazine}

Esra Işık

$\ddot{O} \mathbf{z}$

Erken Cumhuriyet dönemi kadın dergiciliği açısından oldukça verimli bir dönem olmuştur. Osmanlı Devleti'nin son yıllarında basını kullanma gücünü de kazanan kadınlar, bu deneyimlerini Cumhuriyet ilan edildikten sonra da pekiştirmiştir. Kadın dergileri bu bağlamda kadının toplumsal konumunun inşa edilmesinin önemli araçlarından biri haline gelmiştir. Ancak Osmanlı Dönemi’ndeki yayınlardan farklı olarak Cumhuriyet dönemi kadın dergileri, rejiminin kadına sağladığı hakların ve ekonomik koşulların da etkisi ile şekillenmiştir. Bu dergiler, gelecekteki sağlıklı ve güçlü nesilleri yetiştirme vazifesi ile ön plana çıkartılan çağdaş, aydın, üretken ve aynı zamanda geleneksel cinsiyet rollerini sürdüren Türk kadını imajına büyük ölçüde sadık kalmışlar hatta bunu pekiştirmede aktif roller üstlenmişlerdir.

Geliş tarihi (Received): 1.03.2021 - Kabul tarihi (Accepted): 29.05.2021

* Dr. Öğrt. Üyesi, Kütahya Dumlupınar Üniversitesi Fen-Edebiyat Fak. Sosyoloji Bölümü. esra.isik@dpu.edu.tr. ORCID 0000-0003-2983-4183 
Bu makalede Cumhuriyet ile iyi bir eş ve iyi bir anne olarak yeniden tanımlanan kadın imajının dönemin kadın dergilerinden biri olan Ev Kadın dergisinde nasıl yansıtıldığı incelenmiştir. Moda, güzellik, ev işleri, el işleri, mutfak bilgileri, çocuk bakımı gibi konuların yer aldığı derginin adından da anlaşılacağ1 gibi hedef kitlesini ev kadınları oluşturmaktadır. 1945 yılında yayın hayatına başlayan dergi 1950 yılına kadar yayınlanmayı sürdürmüştür. Renkli basılan ve özellikle dönemin batılı moda anlayışını yansıtan kadın fotoğrafları ile dikkat çeken dergi 64. sayısı ile yayın hayatını sonlandırmıştır. Dergide aydın, çağdaş, üretken Türk kadını imajı görsellerle destelenirken, bu imaj aynı zamanda annelik ve eş rolü ile de harmanlanarak sunulmuştur. Bu yönüyle Ev Kadın dergisi dönemin anne ve eş olarak yüceltilen kadın rollerini yansıtmaktadır.

Anahtar sözcükler: erken cumhuriyet dönemi, imaj, kadın dergileri, ev kadın, Türk kadını

\begin{abstract}
The early Republican period has been a very productive era in terms of women's magazine publishing. The women, who gained the power to use the press during the last years of the Ottoman Empire, reinforced their experiences after the proclamation of the Republic. In this context, women's magazines became one of the most important instruments for establishing the social position of women. However, unlike the publications in the Ottoman Period, the Republican period women's magazines were shaped by the rights and economic conditions that the regime provided to women. These magazines largely remained loyal to the image of contemporary, intellectual, productive Turkish women, who were brought to the forefront with the task of raising the future healthy and strong generations and at the same time maintaining their traditional gender roles; moreover, they took active roles in reinforcing this.

In this article, we examined how the image of a woman who was redefined as a good wife and a good mother with the Republic was reflected in the Ev Kadın magazine, one of the women's magazines of the period. As the name suggests, the magazine covers topics such as fashion, beauty, housework, hand crafts, culinary skills, childcare and the target audience are mostly housewives. The magazine, which began its publication life in 1945, continued to be published until 1950. The magazine, which was printed in color and attracted attention with the photographs of women reflecting the Western fashion trends understanding of the period, ended its publication life with the 64th issue. While the image of the intellectual, contemporary and productive Turkish woman has been supported with visuals in the magazine, this image is blended with the role of motherhood and wife. In this respect, Ev Kadin magazine reflects the roles of the women glorified as mother and wife of the era.
\end{abstract}

Keywords: early republican period, image, women's magazines, ev kadın, Turkish women 


\section{Extended summary}

Introduction and purpose: In the Ottoman Empire, the social structure was shaped based on traditional and religious references. This situation had been one of the most important obstacles to women's political and public participation until the 19th century modernization movements. With the declaration of the First Constitutional Monarchy in 1876, the roles of woman restricted to motherhood and spouse at home began to change with the effect of the regulations enacted in education and marriage.

This process also enabled the formation of an enlightened mass of women. During the Second Constitutional Monarchy period, when the effects of this enlightened mass were felt, women's associations were founded, and women's publications increased. Thus, women began to express their wishes and criticisms about their right to education and public participation. The Second Constitutional Monarchy, a time when there was a more liberal environment, was a period when the press became an important tool for women to express themselves and the number of women's magazines increased. These women's magazines, which women of the period used as a tool to announce their demands and complaints regarding the institutional problems, especially education, also carry the traces of the liberal atmosphere of the period. Even though the innovations that were made for Ottoman women who had the opportunity to express themselves through these magazines could not fully participate in social and economic life, the position of women in society have changed significantly

Articles written on topics such as childcare, fashion, beauty and housework also have an important share in these publications, which were met with great enthusiasm by women at the time of publication. On one hand the right to education of women was discussed in the articles but on the other hand, they were also encouraged to be a good wife and mother. This approach was also maintained in women's magazines published after the declaration of the Turkish Republic. In this context, the image of women in the early Republican period women's magazines was presented within the framework of a woman who adopted the Republican values, was Western with her appearance, modern with her education, hard-working, productive and at the same time maintaining traditional female roles. In these magazines, which reflected the image of enlightened women created by the state with all aspects, articles by male writers that answered the question of how the ideal woman of the Republic should be, and sometimes criticized women who did not fit in this image, also had an important place. Ev Kadın magazine, which is the subject of this study, is one of the women's magazines of the period prepared according to this understanding.

Findings: In Ev Kadın magazine, published between 1945 and 1950, topics such as childcare, housework, handicrafts, fashion and beauty were discussed. The magazine is also a publication whose target group was housewives and in which there were articles reminding women of the importance of motherhood and the role of being a wife, which is considered as their primary duty. 
Another remarkable feature of the magazine is that it allows the participation and interaction of its readers. Chapters such as Kadın Şiirleri (Women's Poems), Fizyonomi Tahlilleri (Physiognomy Analysis), Gönül Ablaya Mektuplar (Dear Abby Column), were prepared with the contributions of female readers who followed the magazine. While there were no political content or discussions on women's rights in the magazine, which included the problems thought to be faced by housewives, solutions and recommendations regarding these problems, the issue of education was also put forward in the articles that are advisory on child education. It can be said that the magazine, in which early Republican period's housewifery and the image of women glorified with motherhood were specifically reflected, presented the understanding of modern women largely through appearance, care and behavior patterns.

Method: In this study, document analysis was used as a data collection method. In order to see how the women's understanding of the period was reflected in Ev Kadın magazine, which is among the women's magazines of the Early Republican period, it was examined in terms of content within the framework of the determined themes.

Conclusions: Although they achieved basic civil rights during the early republican period, women were still expected to maintain patriarchal gender roles. Republican women stood out with their modern, productive, educated and at the same time traditional roles. The main mission attributed to women in this period, as a conscious mother and wife, was to raise healthy generations to whom the Republic would be entrusted. Having internalized this task to a great extent, Turkish women became one of the important symbols of the modern and secular new regime with the effect of the economic and political conditions of the period. One of the areas in which this symbol was presented is women's magazines of the period.

In the Ev Kadin magazine, which is examined in this study and is among the periodical women's publications of the period, the image of a woman who performs traditional femininity duties as a good wife and mother, who is self-taught in this context, reflecting the Western fashion sense of the period with her appearance comes to the fore. In this aspect, Ev Kadın magazine reflects an example of the blending of the patriarchal female image with the contemporary female image in the early republican period, which was the main discourse of the women's press, which prospered during the Ottoman renewal period.

\section{Giriş}

Osmanlı Devleti'nin son dönem modernleşme hareketlerinin temel aktörlerinden biri kadınlardır. Klasik dönem boyunca başta eğitim olmak üzere birçok alanın dışında tutulan ve kamusal alana dâhil edilmeyen kadınlar özellikle II. Meşrutiyetle birlikte Osmanlı Devleti'nin değişme çabalarının görünen yüzleri haline gelmiştir. $\mathrm{Bu}$ değişim hem devletin uygulamaları hem de dönemin kadınlarının talepleri ve istekleri doğrultusunda gerçekleştirilmiştir. Geleneksel toplumlarda ataerkil düzenin 
de etkisi ile çocuk bakımı, ev işleri ve hane içinde gerçekleşen üretim sürecine katılımla sınırlandırılan kadın rolleri, erkeklerle kıyaslandığında sosyal ve ekonomik hiyerarşide kadını dezavantajı konuma yerleştirir. Kadın emeği bu süreçte maddi bir karşıllğ̆ bulunmayan ve görünmeyen bir emek haline dönüşür. Osmanlı Devleti’nde de geleneksel kodlar kadının bu konumunu pekiştirmiş, çalışma fırsatı bulan kadınlar bile sınırlı bir emek piyasası içinde ucuz işgücü oldukları ve evden çıkmadan üretim yaptıkları için tercih edilmiştir. Bu enformel emek kadının toplumsal konumunun uzun yıllar değişmeden sürmesine neden olmuştur. 1800'lü yıllarda kadınların en fazla çalıştığı iş kollarından biri olan tekstil sektöründe bile kadın emeğinin tercih edilme nedeni ucuz olması ve kadının ailenin geçiminde temel direk olmadığı kanısıdır. Nitelikli bir kadın el işçisi bile kalifiye bir erkek kalfanın yarı ücretine çalıştığ 1 için kadın emeği ihtiyaç halinde başvurulan sınırlı ve kolay vazgeçilebilir bir emek olarak kalmıştır (Vatter, 1998: 84). Bu bağlamda Osmanlı Devleti'nde yenileşme dönemine kadar ataerkil düzenin ve dinin etkisi ile ekonomik ve toplumsal hayatta sınırlandırılan kadının konumu XIX. yüzyıldan itibaren değişmeye başlamıştır.

Özellikle I. Meşrutiyet'le birlikte kadınların eğitim olanaklarının biraz daha genişletilmesi, kadınlara boşanma hakkı tanınması ve çok eşliliğin kadının rızasına bırakılması ile kadının sosyal hayata katılımının önünü açılmış bu düzenlemelerin etkisiyle de aydın bir kadın kitlesi oluşmaya başlamıştır (Gelgeç Bakacak, 2009: 629). I. Meşrutiyet'le oluşmaya başlayan bu aydın kadın kitlesinin somut etkileri özellikle 1908 'den itibaren hissedilmiştir. II. Meşrutiyet döneminin özgürlükçü ortamı ve bu dönemde toplumda yaşanan yapısal dönüşümlerin tesiri ile kadının değişen gözlemlenebilir konumu ve farklı bir statü kazanmak amacı ile dile getirmeye başladığı talepler o zamana kadar ev içinde annelik ve eş rolleri ile sınırlandırılan kadınlara da yansımıştır. Bu dönemde kurulan kadın dernekleri, çıkartılan süreli yayınlar ve düzenlenen konferanslar aracılığı ile sorunlarını, beklentilerini dile getirme firsatı bulan Osmanlı kadını için özellikle basın önemli bir araç haline gelmiştir (Çakır, 1996: 22). Dönemin kadın dergileri bir taraftan kadınların kendilerini ifade etmelerine olanak sağlarken diğer taraftan da verdikleri tavsiyeler, bilgiler vasıtası ile dönemin kadınlarını aydınlatmayı görev edinmiştir. II. Meşrutiyet öncesi dönemde de kadının mevcut toplumsal konumuna ilişkin eleştirel yazılara rastlanmaktadır. Örneğin 1868 yılında yayınlanmaya başlanan Terakki Gazetesi'nde kadının geri bırakılmasını eleştiren yazılar yer almış, bazılarının yayın sorumlularının kadınlar olduğu Vakit, Şuküfezar, İnsaniyet, Ayine, Parça Bohçası, Aile gibi gazeteler de, çoğu kısa ömürlü olsa da, özellikle devrin kentli kadınlar1 tarafından merakla takip edilen yayınlar haline gelmiştir (Tekeli, 1982: 196-197). 1880 yılında yayınlanan Aile Dergisi adlı yayın ise ilk çıkan kadın dergisi olarak kabul edilebilir. Mihran ve Muharriri ile Şemsettin Sami’nin sahibi olduğu Aile Dergisi’nde çocuklara, kadınlara ve ev işlerine yönelik yazılar yer almıştır (Özen, 1994: 17).

1908 yılında II. Meşrutiyet'in ilan edilmesi ile kadın dergilerinin sayısında patlama yaşanmış, aynı yıl yayınlanan Demet adlı kadın dergisini Mehasin, Kadın, Mefharet adlı dergiler takip etmiştir. Kadınların siyasi konularla ilk tanıştığı dergi olan 
Demet dergisinin birinci sayısında hiç kadın yazar yer almazken sonraki sayılarda kadın yazarlar çoğunluktadır (Çakır, 1996: 33). Dergide işlenen konuların önemli bir bölümünü kadınların eğitimi, çocuk bakımı, kadın terbiyesi, yüz bakımı ve moda oluştururken yine dergide yer alan siyasi içerikli yazılar da kadınlar tarafından büyük ilgi ile karşılanmıştır. Demet renkli ve resimli olarak yayınlanan ilk kadın dergisi olması yönüyle de kadınlara dair süreli yayınlar içinde önemli bir yere sahiptir (Özen, 1994: 25). Dönemin reform hareketleri kadının toplumsal konumunun iyileştirilmesi, ekonomik ve kültürel yönden kadının sosyal hayata katılımının tam anlamı ile sağlanması noktasında yeterli olmasa da kadınlar bu süreli yayınlar aracılı̆̆ getirme fırsatı yakalamışlardır. Bu isteklerden biri Darülfünun 'da kadınlara yönelik gerçekleştirilen konferansların daha geç saatlere alınmasıdır. Özellikle Kadın Hukuku dersi için değişiklik yapılmasını talep eden kadınların isteği dönemin önemli bir yayını olan Kadınlar Dünyası'nda yazılan makaleler ve mektuplarla ses getirilince bu durum bilinçli bir kamuoyu oluşmasına da yol açmıştır (Çakır, 1996: 246).

Nuriye Ulviye (Mevlan)'nin sahibi olduğu ve İstanbul'da 1913-1921 yılları arasında haftalık yayınlanan Kadınlar Dünyası adlı dergi bu bağlamda kadınların hukukunu savunan ve yayın politikası ile diğer kadın dergilerinden ayrılan bir süreli yayındır. Yazarlarının hepsinin kadınlardan oluştuğu dergi aynı zamanda Meşrutiyet döneminde kurulan ve feminist bir söyleme sahip olan, kadın haklarını savunan Osmanlı Müdâfaa-i Hukuk-1 Nisvan Derneği'nin de çıkış noktası olmuştur (Ateş, 2009: 24-25). Meşrutiyet döneminde yayınlanan gazete ve dergiler sadece kadın haklarının savunulması ve kadınların taleplerinin duyurulması amacına hizmet etmemiş aynı zamanda kadınların bireysel sorunlarını yazabilecekleri ve çözüm bulabilecekleri bir platforma dönüşmüştür. Kadınlara çeşitli konularda tavsiyeler veren yazıların yer aldığı bu yayınlar dönemin kadın yazarların sayısının artmasına da yol açmıştır. Erkek yazarlara da yer verilen dergi ve gazetelerde kadın hakları, eğitim, kadının toplumsal konumu gibi çeşitli hususlarda yazılar yazılırken, yayınlanan makalelerde çalışma hayatı, annelik, çocuk bakımı ve siyasette önemli bir yer tutmuştur.

Osmanlı'nın son döneminde gerçekleştirilen yenilikler aracılığı ile başta eğitim hakkı olmak üzere bazı haklara kavuşan kadınların sosyal hayata katılımının önü açılmıştır. Özellikle kentli Osmanlı kadını için diğer dönemlerle kıyaslandığında II. Meşrutiyet önemli bir özgürlük ortamının oluşmasına ve kadının geleneksel rolleri dışında yeni roller kazanmasına yol açmıştır. Tanzimat döneminde var olan 13 yayının sadece 2'si kadınlar tarafindan çıkartılırken, Meşrutiyet ile yayınlanmaya başlayan 22 gazete ve derginin 4'ünün yayıncısı kadınlardır. Bu süreçte aynı zamanda erkeklerin çıkarttığı yayınlardan yine 4'ünde kadınlar müdür veya başyazar olarak görev almışlardır. Yaklaşık 27 kadın gazete ve dergisinin basıldığı bu dönemde kadınların aktif olarak yer aldığı, makaleler yazdığı süreli yayınlar, kadınların eğitimi ve ekonomik hayata katılımları konusunda da etki yaratmış, bu yayınlar aracılığı ile oluşturulan kamuoyu Cumhuriyet dönemi inkılaplarının da önemli dayanaklarından biri olmuştur (Kurnaz, 1991: 95). Kadının öncelikli rolünün iyi bir eş ve anne olarak görüldüğü, kadın eğitimi- 
nin lüzumuna inanılmayan ve kadın emeğinin hane içinde görülmeyen bir emek olarak kaldığı bir sistemde kadınların yükseköğrenim için mücadele etmesi, kadın hakları tartışmaları yapması, dernekler kurması, yürüyüş ve konferanslar düzenlemesi toplumsal değişimin işaretleridir. Bu değişime aracılık eden ve yön veren kadın yayınları Osmanlı Devleti'nin yenileşme hareketleri içerisinde kadın eğitiminin önemine ilişkin düşünce ve görüşlerin topluma yayılmasını ve konunun tartışmaya açılmasını da sağlamıştır.

II. Meşrutiyet ile başlayan süreç genel anlamda kadın hareketlerinin ön plana çıtığı ve kadının toplumsal görünüm elde etme arzularının da yön verdiği bir dizi değişimin gündeme geldiği dönem olarak da görülebilir. Toplumda ortak bir kadınlık bilincinin oluşturulması ve Osmanlı kadınının batıdaki hemcinsleri gibi özellikle eğitim hakkına kavuşması mücadelesinde kadın yayınları önemli birer araç olmuştur. Ancak bu yayınlarda ataerkil kalıplardan bağımsız ve özgün bir kadın imgesi sunulmamaktadır. Dönemin modern kadın imajının arkasında ataerkillik saklıdır ve dergilerde işlenen temalar bir şekilde ev işleri, iyi bir eş olma ve annelik kavramları etrafında sürdürülmüştür. Kadınların ve özellikle genç kızların eğitimi söz konusu olduğunda bile öncelik hala bu üç kavrama dayalı olarak şekillenmiştir (Akagündüz, 2012: 343). Dönemin fikir akımlarında bile bu önceliği görmek mümkündür. Türk kadının eğitilmesi isteği üç fikir akımında da ortak görüşlerden biridir ancak bu eğitim İslamcılara göre iyi bir ev hanımı olabilmenin şartı iken, Türkçüler ve Batıcılar aile hayatı yanında kadının eğitiminin sosyal hayata katılımı için önemli olduğu görüşünden hareket etmişlerdir (Kurnaz, 1991: 77). Bu bağlamda kadının toplumsal, siyasi ve ekonomik konumuna dair tartışmaların Osmanlı son dönem yenileşme hareketlerinde önemli bir yer işgal ettiği söylenebilir. Kadın yayınları da bu tartışmalara yön veren bir alan yaratması bakımından değişen kadın imajının beslendiği temel dinamiklerin anlaşılması noktasında son derece önemlidir. Çünkü erken Cumhuriyet dönemi kadın politikaları da büyük ölçüde bu imajın sürdürülmesine yönelik bir dizi uygulamaya dayanmaktadır. Bu sürekliliği erken Cumhuriyet dönemi kadın yayınlarında da görmek mümkündür.

\section{Erken Cumhuriyet dönemi kadın imajı}

Millî Mücadele döneminde önceliği vatan olan ve faaliyetlerini bu önceliğe göre şekillendiren kadınlar hem bizzat cephede savaşmış hem de cephe gerisinde milli mücadele ruhunu oluşturmaya ve canlı tutmaya yönelik hizmetlerde bulunmuşlardır. Bu amaçla mitingler düzenleyen, yardım faaliyetleri organize eden ve cemiyetler kuran kadınlar aynı zamanda gazetelerde yazdıkları yazılarla da bağımsızlık mücadele azmini ayakta tutmaya çalışmışlardır. Halide Edip, Müfide Ferit gibi dönemin önemli kadın kalemlerinin Hâkimiyet-i Milliye ve İrade-i Milliye gazetelerinde yazdıkları yazılar, psikolojik bakımdan etkili olmuştur (Kurnaz,1996: 64-68). Kadınların bu azmi ve çabası neticesinde Cumhuriyet kurulduktan sonraki kadın söylemlerinde temel referanslar büyük ölçüde "Türk kadınının fedakârlığı" üzerine kurulmuştur.

1924 anayasası ile her alanda çalışma elde eden kadınlara, 1930 yılında belediye seçimlerine katılma ve 1934 yılında da milletvekili seçme ve seçilme hakkı veril- 
miştir. Eğitim sisteminin laikleşmesi, medeni kanunun kabulü ve kıyafet kanununun çıarılması gibi Cumhuriyet'in kadın devrimi olarak nitelendirilebilecek diğer değişikliklerle, kadının hukuki statüsünü belirleyen dini esasların yerini Batılı toplumlardaki gibi hukuki esaslar alınca yasa önünde kadın ve erkek eşitliği sağlanmıştır (Tekeli, 1983: 1193). Cumhuriyetin ilanı ile birçok alanda temel haklara ve eşitliğe kavuşan Türk kadını için geriye bu haklara uygun davranışlar sergilemek kalmıştır. Dönemin kadın dergilerinde de bu durumun yansımalarını görmek mümkündür. Kadınların Cumhuriyet döneminde Osmanlı'nın son dönemindeki gibi hak ve kimlik mücadelesi kaygısı taşımamalarının nedeni hem elde etikleri bu haklar hem de ekonomik dinamiklere ilişkin yaşanan değişimlerdir (Mutlu, 2009: 60). Cumhuriyet dönemi kadın imajı da bu doğrultuda şekillendirilmiştir. Cumhuriyet'in ideal kadın kimliğinin iki temel bileşeni vardır, kamusal ve ekonomik alanda varlık gösteren eğitimli, çağdaş Türk kadını ile ahlaki ve geleneksel yükümlülüklerine uygun roller sergileyen Türk kadını. Bu çerçevede yeni dönem kadına yüklenen temel misyon iyi ve eğitimli bir anne ile eş olmaktır ve bu misyona dair çizilen kadın imajı da Osmanlı Devleti'nin son dönemindeki kadın imajına paralel bir seyir izlemektedir.

Kadın her ne kadar kamusal alana çıkmış olsa da Cumhuriyet ideolojisi ataerkil sistemi bir şekilde yeniden üretmiş, eğitime teşvik edilen kız çocuklarından aynı zamanda "iffetli" olmaları beklenmiştir. Kadına verilen en önemli görev annelik ve eş rolünü yerine getirmesidir (Lüküslü, 2009: 36-37). İyi bir anne ve eş olmak demek aynı zamanda Cumhuriyet'in emanet edileceği sağlıklı ve eğitimli kuşaklar yetiştirmektir. Bu doğrultuda yeni rejimde sağlıklı nesiller yetiştirme görevi hem kadınların hem de eğitim sisteminin sorumluluğuna bırakılmış, özellikle beden terbiyesi aracılığ ile güçlü genç bir nesil oluşturulmaya çalışılırken, sağlık politikaları aracıllı̆̆ ile bu neslin niceliksel olarak arttırılması hedeflenmiştir (Akın, 2004: 92-93).

$\mathrm{Bu}$ bağlamda gerek görüntüsü gerek aldığı eğitim gerekse sahip olduğu haklar ile yeni ülkenin de simgelerinden biri haline gelen Cumhuriyet kadını imajının devlet tekelinde olan radyo ve televizyonda da 1970'lere kadar sürdürüldüğü görülür. Dönemin kadınlara dair hazırlanan programları kadınlara nazik hanımlar, saygıdeğer ev hanımları ve kutsal anneler muamelesinin yapıldığ 1 bir alan olarak ön plana çıkarken, ilk kez 1939 yılında gerçekleşen kadına yönelik radyo programları kadına evin anası olmanın dışında bir kimlik tanımadan önce "Evin Saati" ve daha sonra da "Ev" adını alarak başlamıştır (Saktanber, 1991: 216). Benzer yaklaşım yine dönemin kadın basınının önemli aracı olan kadın dergileri tarafından da sürdürülmüştür. Erken Cumhuriyet dönemi kadın dergileri de iyi bir anne ve iyi bir eş olma vazifesi ile yüceltilen kadın söylemine büyük ölçüde sadık kalmışlardır.

\section{Erken Cumhuriyet dönemi kadın dergileri}

Erken Cumhuriyet döneminde her ne kadar hukuksal anlamda kadın-erkek eşitliği sağlanmış olsa da geleneksel ataerkil toplumlardaki toplumsal cinsiyet rollerinin biçimlendirdiği kadına dair beklentiler sürdürülmüştür. Cumhuriyet rejiminin 
kadından beklediği asli rol annelik ve iyi bir eş olmaktır. Bu rolün basın aracılığı ile nasıl sunulduğunun ve içselleştirildiğinin izlerini süreli kadın yayınlarında görmek mümkündür. Dönemin kadın dergilerinde ve gazetelerinde çalışan kadın imajının ev kadını ve aile kadını imajları ile aykırılık teşkil etmeden sürdürülmesinin ve kadının anne ve eş olarak öncelikli görevlerini yerine getirmesinin önemi vurgulanmaktadır. $\mathrm{Bu}$ çerçevede dönemin kadın yayınlarının ağırlıklı olarak üzerinde durdukları konular ahlak, ev idaresi, çocuk bakımı-sağlığı, evlilik, moda gibi kadınlara dair eğitici, öğretici ve aynı zamanda teşvik edici konulardır (Gelgeç Bakacak, 2009: 634). Bu konular, dönemin kadın imajının temel hatlarının ne şekilde oluşturulduğunu ve bu imajın hangi esaslara yönelik belirlendiğini de ortaya koymaktadır.

1930'lara kadar basılan ve erkeklerle eşit hak ve özgürlükleri hedefleyen kadın imgelerinin yer aldığı Süs (1923), Ev Hocası, Çalıkuşu (1923), Yıldız, Firuze (1924), Resimli Ay Mecmuası (1924), Asar-ı Nisvan (1925), Yeni Kitap (1928) ve Hanımlar Alemi (1929) gibi dergiler dönemin ilk kadın yayınları sayılmaktadır. 1930'lardan sonra ise kadın dergileri artmış, yeni dergiler yayınlanmaya başlamıştır. Önemli bir bölümü aylık periyodlarla çıkartılan ve ideal Cumhuriyet kadını imajını pekiştiren bu dergiler arasında ise Elişi (1930), El Emekleri, Aile Dostu (1931), Salon, Cumhuriyet Kadını (1934), Moda Albümü (1936), Model (1937), Ev-Iss (1937), Okul Kızı (1937), Ana (1938), Sesimiz (1940), Kadın Dünyası (1940), Kadinlar Âlemi (1940), Ev-Kadını (1943), Asrın Kadını (1944), Ev Kadını (1945), Aile (1947), Kadın Gazetesi (1947), Hanımeli (1947), Yeni Moda (1948), Seksoloji (1949), Yeni Holivud Magazin (1948), Büyük Moda Mecmuası (1949), Familya (1949), Dişi Kuş (1949), Hemşirelik Dergisi (1950) gibi dergiler sayılabilir (Şahin, 2018: 98-99). Devlet eliyle oluşturulan aydın kadın imajını bütün yönleri ile yansıtan bu dergilerde erkek yazarların kaleminden Cumhuriyet'in ideal kadın anlayışının nasıl olması gerektiği sorusuna yanıt veren ve kimi zamanda bu imajın dışında kalan kadınları eleștiren makaleler de önemli bir yer tutmaktadır.

Dönemin süreli yayınları arasında yer alan Türk Kadını dergisinde "Kadın Psikolojisi" adlı yazısında Dr. Muzaffer Sezer ideal kadın tipini (aydın) ayrı tutarak kadınların üç sınıfa ayrıldığından bahsetmektedir. Sezer'e göre bu farklı sınıflara mensup kadınlar dışındaki aydın Türk kadını, makbul olan ve geleceğe dair inancı ve güveni arttıran kadındır. Dr. Muzaffer Sezer bu kadınları şöyle tarif etmektedir:

\footnotetext{
"Bereket versin ki bu pek mahdut olan kadın ruhu yanında ekseriyeti evini, çocuklarını düşünen, bütün saadetini kocasının yanında onun yükselmesinde, kazanmasında bulan ve bunu hisseden saf ve temiz kalbli kadınlarımız teşkil eder. Dejenere olmaktan kurtulmuş bir nesli ileri devirlere intikal ettirecek temiz ve âsil ruhlu tam aydın kadınlarımızdır ki, geleceğe daha güvenli adımlarla yürümek zevk ve saadetini bize veriyor ve bizi rahat bir yürekle yarına bağlıyor." (1945-12: 3-4).
}

Yine dönemin önemli yayınlarından biri olan Ana dergisinde yer alan bir yazıda da insanların bütün isteklerinin gerçekleştirilmesinin mümkün olamayacağından bahsedilmekte ve özellikle hudutsuz isteklerde bulunan tatmin edilmeyen kadınlara 
dikkat çekilmektedir. Bu kadınlar için gezmek, elbise almak tatmin olmanın yollarıdır ancak bir isteğin yerine gelmesi diğer bir isteği ortaya çıkartır. Yazıda ev kadınını tatmin etmenin çaresinden de şu şekilde bahsedilmiştir:

\begin{abstract}
"Ev kadınını tatmin etmek, onu ocağına merbut bir unsur haline koymak için bir çare yok mudur? Vardır. O da ev kadınının ana olmasıdır. Kadının birçok emellerini, heveslerini, ihtiraslarını kucağındaki yavrusu uyutur. O yavrunun sevgisi, analık hissi kadında başka isteklere meydan bırakmaz. Çocuğunun bir tebessümü anaya, birçok hislerinin tatmin edilmesinden daha üstün bir zevk, bir haz verir" (1938-6: 4).
\end{abstract}

Erkeklerden daha çok kadınlarda var olduğu düşünülen tatmin edilmek isteğinin annelikle ortadan kalkacağının belirtildiği yazıda, çocuk yetiştirmenin, onun cıvılttısını dinlemenin elbise, ayakkab1, manto, kürk vb. alma hevesini ortadan kaldırarak kadına huzur ve mutluluk vereceği söylenmektedir. Ancak bu söylemin aksine aynı dergide manto örnekleri, giysi kalıpları, şapka satın almak isteyen kadınlara yönelik şapka model önerileri, yazlık-kışlık ve günlük kıyafet tavsiyeleri de yer almaktadır.

Erken Cumhuriyet dönemi kadın dergilerinde Türk kadınının annelik ve eş rolleri yüceltilirken, devrin tanınan batılı kadın figürlerinden de sıkça örnekler verilmektedir. Bu dergilerde Türk kadınına batılı hemcinslerinin anlatıldığı makalelerde söz konusu kadınlar ev hayatı ve evliliğe dair olumlu ve teşvik edici düşünceleri çerçevesinde sunulmakta hatta bu tanımış simaların başarıları ev işlerindeki ve annelikteki maharetlerine bağlanmaktadır.

Örneğin Türk Kadını dergisinde Joan Crawford ile ilgili bir yazıda Amerikalı oyuncunun güzelliğinden ve giyiminden övgü ile bahsedilmekte, bunun yanında aktristin ilerleyen yaşına rağmen bir genç kızdan farksız olması hareketliliğine, ev işlerini görmeyi bir zevk edinmesine, yemek pişirip, bahçe işleri ile ilgilenmekten haz almasına bağlanmaktadır. Joan Crawford hakkındaki yazı aktristin "Merak etmeyin, evleneceğim” beyanı ile son bulmaktadır (1948-10: 13). Tahsin Demiray'ın sahibi olduğu aylık yayınlanan Yıldız (1924) adlı dergide de sadece kadın oyunculara değil erkek oyuncu ve sanatçılara da yer verilmekte, Avrupa'dan, Amerika'dan magazinsel haberler, film tanıtımları, Hollywood modasına dair bilgiler zengin görsellerle okura sunulmaktadır.

Dönemin süreli yayınlarında annelik ve ev işleri görme vazifesinin yüceltildiği ve kadına dair uygun görülmeyen davranış ve tutumların (kıskançlık, tatminsizlik, bakımsızlık, dağınıklık vb.) eleştirildiği yazılar da kendine yer bulmaktadır. Bu yazılarda kötü davranışların zararlarından bahsedilirken iyi bir eş ve bilinçli bir anne olma rolü Türk kadınının en kutsal vazifesi olarak yüceltilmektedir:

"Bu kadar karışık ve güç vazifelerin başında kadının asîl ve kutsal bir ödevi vardır: ANALIK! Ana kadınlık!. İşte bütün mesele buradadır. Dâvamız ve ele aldığımız kadın tipi de budur. Cemiyet: bu ana vasıftan meydana gelir. Yoksa her dişiyi bir kadın olarak ele almıyoruz....Hakiki bir kadın, her şeyden önce (İdeal bir Anne) olmakla kendini gösterir. Kadına, kadınlık denen şeref kupası ancak o zaman verilir" (1944-7: 2). 
Turhan Toker tarafindan Türk Kadını dergisinde kaleme alınan Kadın ve En Kutsal Vazifesi başlıklı bu yazıda da söz konusu vazifenin ehemmiyeti üzerinde durulmakta, hatta bu vazifeyi yerine getirmeyen kadınların kadın olarak ele alınmadığ 1 keskin ve net bir üslupla ifade edilmektedir. Genel olarak bakıldığında erken Cumhuriyet dönemi kadın dergilerinde Cumhuriyet'in aydın Türk kadını imajı, görgüsü bilgisi ve dış görünüşü ile çağın şartlarını yakalayan, çocuk bakımı, sağlık, ev işleri konusunda beceri ve donanıma sahip olan, eğitimli ve aynı zamanda yeni rejimin kendisine sağladığı temel hak ve hürriyetlerin bilincinde bir kadın olarak sunulmaktadır. Bu imaj bir taraftan geleneksel cinsiyet rollerinin sürdürüldüğünün, diğer taraftan da yeni kurulan bir devletin ihtiyaç duyduğu, sağlıklı nesilleri yetiştirecek aydın kadın anlayışının neticesidir.

Sancar'ında (2014: 112) ifade ettiği gibi dönemin siyasal reform süreçlerinde yer almış kadınlar, Cumhuriyetin kurucu erkekleri ile eşit konum ve statüde devleti yöneten ve toplumsal firsatlardan yararlanan vatandaşlar olmak yerine ulusun anaları, geleneğin ve milli kültürün taşıyıcıları olarak konumlandırılmışlardır. Bu modern Türk kadını kimliği eşit vatandaşl1k statüsünden çok Türk milli ve modern kimliğini dünyaya sunan bir kültür göstergesidir. Cumhuriyet'in ilk yıllarında yeni kurulan devletin modernliği, rejimin ikonografisinde kilit önem taşıyan kadın imgeleri (geçit törenlerinde bayrak taşıyan şortlu, okul önlüklü ya da asker üniformalı genç kızlar ya da balo salonunda dans eden tuvaletli kadınlar) aracılığı ile simgelenmiştir (Kandiyoti, 1999: 112).

$\mathrm{Bu}$ anlayış çerçevesinde dönemin kadın modeli, iş hayatında eğitimli profesyonel; topluluklar, kulüpler kuran, buralara katılan sosyal bir kadın olarak ön plana çıkar. Bu modelle özdeşleştirilen Türk kadını, uygun eğitim ve terbiye almış anne ve eş olmanın yanında gece kıyafetleri içinde balolarda dans eden, erkeklerle birlikte eğlenen feminen kadındır. Bu rollerden ilk üçü, daha önceden Osmanlı döneminde tecrübe edilmişken, sonuncusu yenidir ve Cumhuriyetle birlikte, Batı tarzı kadınerkek ilişkileri kurulmasını hedefler (Acun, 2007: 98).

$\mathrm{Bu}$ çalışmada ele alınan dönemin kadın dergilerinden biri olarak Ev Kadın dergisinde de söz konusu kadın imajını yansıtan bu anlayışın sunumunu görmek mümkündür. Dergide Türk kadınına bir taraftan geleneksel rollerini (iyi bir eş, anne ve ev kadını) sürdüren diğer taraftan ise modern Cumhuriyet'in Batıya dönük yüzünü (dış görünüşü, kamusal görünürlüğü, sosyal hayata katılımı ve eğitimi ile) layıkıyla temsil eden bir anlayış içinde yaklaşılmıştır.

\section{Ev kadın dergisi}

Erken Cumhuriyet dönemi kadın yayınlarından biri de Ev Kadın adlı aylık dergidir. $\mathrm{Bu}$ dergi de diğer kadın dergileri ile paralel bir kadın imajı sunmanın yanında moda, el işi, yemek tarifleri, giyim kalıp ve örneklerine yer veren ve aynı zamanda dönemin kadınlarının sorularını ve sorunlarını sayfalarına taşıyan aylık süreli bir yayındır. M. Faruk Gürtunca'nın sahibi olduğu derginin kapak sayfasında yayının adı Ev Kadın şeklinde yer alırken, iç sayfalarda Ev ve Kadın Dergisi ifadesi dikkat çekmektedir. 
Ev Kadın dergisinin yazı işleri müdürlüğü M. Hulki Ekler tarafından yapılmıştır. 1945 yılında yayın hayatına başlayan, 30 sayfa ve renkli olarak basılan, dönemin ev kadınlarına yönelik yazıları ile ön plana çıkan ve her ay okurlarına ilave bir pafta veren dergi 64. sayısı ile 1950'de son kez basılarak yayın hayatını tamamlamıştır (Özen, 1994: 40).

Ev Kadın dergisinde özellikle ev kadınlarının kendilerini çeşitli yönlerden geliştirebilecekleri pratik bilgiler, kadınlar tarafından yazılan mektuplar, şiirler ve düzenli olarak her sayıda, bir devamlılıkla yer verilen romanlar bulunmaktadır. Dergiye dair dikkat çekici bir diğer detayda sayfalarda sıklıkla karşılaşılan reklamlardır. Ev Kadın dergisinde okurların sosyal profillerine uygun elişi mağazası, iplik, bebek maması, kitap ve yayınevi ile kadın hijyen ürünleri reklamlarına rastlanmaktadır. Aynı zamanda yabancı markalı; saat, elektrik süpürgesi, dikiş makinası gibi ürünlerin reklamlarının da yer aldığı derginin her sayısının kapağında farklı bir kadın fotoğrafı kullanılmıştır.

Ev kadınlarının hedef kitle olarak görüldüğ̈̈ Ev Kadın dergisinin tasarım ve içeriği de buna göre hazırlanmıştır. Bakımlı, güzel ve dikkat çekici kadın görselleri, saç ve vücut bakım önerileriyle, yemek tarifleri, temizlik yapmanın püf noktaları ile yan yana sunulmuştur. Evi ve ailesi ile ilgilenen, bilgili, dış görünüşüne dikkat eden ve kültürlü Türk kadını imajı dergideki genel kadın profilini oluşturmaktadır. Bu imaj dönemin kadın dergilerinin de ortak paydasıdır. Tüketici dergiler grubuna giren bu kadın dergileri reklam destekli dergiler olup Batıda da yaygın olarak mevcuttur. Özellikle 1800'ler de Amerika' daki kitle dergileri arasında en başarılısı olan kadın dergileri erken Cumhuriyet dönemi dergilerinde olduğu gibi aile bağlarının idealleştirildiği bir dönemde ev işleri, giyim, mutfak gibi konuları ön plana çıkaran yayınlar olarak binlerce okura ulaşmışlardır. 1930'lardan itibaren ise yeni kadın tüketici imajının yön verdiği sektör, iki farklı kadın okuyucu tipine ve ekonomik yapının etkisine bağlı olarak çeşitlenmiştir. Bu dönemde bekâr ve çalışan kadın ile evli ve çalışan kadın profili yaşanılan kültürel değişimlerin sonucu olarak ön plana çıkmıştır (Peltekoğlu, 1995: 117-118). Erken Cumhuriyet dönemi kadın dergilerinde ise bekâr ve çalışan kadın tipine ilişkin yazılara yer verilmemiştir. Aksine evli, evinin ve ailesinin sorumluluğunun bilinci ile hareket eden ve sağlıklı çocuklar yetiştirme görevi ile yüceltilen aydın Türk kadını imajı dönemin kadın dergilerinde sunulmuş, kadınların farklı alanlardaki başarılarına değinilen yazılarda bile kadına öncelikli vazifesi olan annelik ve eş rolü hatırlatılmıştır.

\section{Ev kadın dergisinde kadın imajının sunumu}

Ev Kadın dergisinde dış görünüş bakımından Batıyı örnek alan ancak kendisinden beklenilen öncelikler bakımından geleneksel cinsiyet rollerini sürdüren kadın figürü ön plana çıkmaktadır. Bu imaj ev kadınlılarına yönelik derginin yazılarında ve hatta görsellerinde de ortaya konulmuştur. Cumhuriyet dönemi kadın dergiciliğinde Cumhuriyet kadını nitelemesine uygun kadın tipi sunumu diğer dergilerde olduğu 
gibi Ev Kadın dergisinde de açıkça görülmektedir. Makyaj, saç ve giyim konularını gündeme taşıyarak Türk kadınının dış görünüşü ile modernliği yakalaması gerektiğinin altını çizen kadın dergileri kullandıkları kapak resimleri, ele aldıkları konularla Avrupalı kadını örnek almışlardır (Mutlu, 2009: 61). Ev Kadın dergisinde işlenen konular, yazılan makaleler ve öneriler aracılığı ile bu eğilim sürdürülmüştür.

Ev Kadın dergisinde bu bağlamda yer verilen belli başlı konular şunlardır:

Çocuk Bakımı: Derginin temel kanunlarından biri olan çocuk bakımı, sağlıklı çocuklar yetiştirilmesine ilişkin tavsiyelerin yer aldığı yazılarla dergide önemli bir yere sahiptir. Çocuk bakımı konusunda köşe yazılarının da olduğu Ev Kadın dergisinde Dr. İclal Ataer tarafından hazırlanan Gürbüz Çocuk Yetiştirmek adlı bölümde çocuk hastalıklarına dair bilgilere, doğru bilinen yanlışlara her sayıda düzenli olarak yer verilmiştir. Ayrıca Gürbüz Çocuk Fotoğrafları köşesi ile de sağlıklı çocuk görsellerini sayfalarına taşıyan dergi, aynı zamanda çocuk kıyafetlerinin nasıl hazırlanacağına dair önerileri ve çocuklar için sağlıklı yemek tariflerini de içermektedir.

Bakım ve Moda (Dış Görünüş): Ev Kadın dergisinde kadın modasına dair yazılar, güzellik önerileri, dönemin sinema yıldızlarının giyim analizleri, jimnastik ve yoga hareketleri ile cilt bakımı da yer bulmaktadır. Kadınların hangi ortamda nasıl davranmaları gerektiğine dair ipuçları veren dergide modaya uygun giyinmenin önemine dikkat çeken yazılara da sıkça rastlanmaktadır. Dergi aynı zamanda erkek okurlara da tavsiyeler vermektedir. Samiye Birsen tarafindan kaleme alınan Sosyete Bilgileri başlıklı yazıda danslı bir çalgıya, dügüne, baloya veya herhangi bir danslı toplantıya gidildiğinde erkeklere nasıl hareket etmesi ve nelere dikkat etmesi gerektiğine dair şu uyarılar yapılmaktadır:

“İçkiyi itidalle için. Çok içmekle hem kendinize zarar vermiş, hem de başkalarını da gücendirmiş olursunuz....Karınızla dans ederken onu bırakıp, hafif ve delişmen bir kızla dansedemezsiniz. Şunu da unutmayınız ki dansederken flört yapmak hevesine kapılmamak lazımdır.” (1949-56: 28).

Ev Dekorasyonu ve El işleri: Evin dekorasyonu ve el işi bilgileri Ev Kadın dergisinde ele alınan diğer konulardır. Kadınların yaşam alanlarını temiz ve düzenli tutmasına ilişkin yazıların yanında ev süslemeye dair önerilere de yer verilen sayfalarda, tepsi örtüsünden perdeye, çocuk odası dekorasyonundan yorgan kapağı yapımına, nakış işlerinden, örgü örme ve dikişe kadar geniş bir yelpaze de hazırlanmış tarif ve tavsiyeler yer almaktadır. Evin düzenli ve tertipli olmasını kadının en önemli görevlerinden biri olduğunu ifade eden yazılarda eve ait küçük ayrıntıların bile ne kadar etkili olduğu vurgulanmaktadır:

"Bazı kadınların ev hali biraz dağınık ve derbederdir. Bazıları da yaradılıştan geniş yürekli oldukları için ev işlerini ihmal ederler. Halbuki bugün sosyete icabı ve etiketin hüküm sürdüğü yerlerde, her kadın evinin intizam ve nizamına ve dikkat etmek durumundadır. İnsanlar meraklı ve mütecessistirler. Her şeyin bozuk tarafını görürler. Fakat bilgili ve kültürlü bir ev kadını bunlara lâyık olduğu önemi verdiği için hiçbir zaman mahcup duruma düşmez" (1949-51: 21). 
1949 yılında yayınlanan 51. sayıdaki bu yazının başlı̆̆ı Vazo Altları' dır. Evlerde kullanılan vazo altlarının bile kadının düzenli ve tertipli olması ile ilişkilendirildiği yazının sonunda dergi ile paftası verilen vazo altlığı örneğinin dergide reklamı sıklıkla yer alan bir iplik markasının renkli iplikleri ile işlenebileceği belirtilmiştir.

Ev Kadın dergisi aynı zamanda yemek tariflerinin, hazır yemek listelerinin olduğu bölümlere de yer vermektedir. Özellikle bebek maması ve çocuklar için sağlıklı yemek hazırlamanın inceliklerine değinen yazıların yanında misafirlere sunulacak ikramlıklarda derginin içeriğinde yer almaktadır. Dönemin Kız Sanat Okulları kadın öğretmenlerinden Esat İren'in hazırladığı Yemek Yapalım bölümü de yemek tariflerinin yer aldığı sürekli köşelerdendir.

Dergide dikkat çeken bir diğer özellik de okuyucuların katılımına ve okuyucularla etkileşime imkân tanıyan yazılardır. Ev Kadın dergisinde düzenli olarak yayınlanan Kadın Şiirleri bölümünde şiirle amatör olarak ilgilenen adın şairlerin ülkenin farklı illerinden gönderdikleri dizelere yer ayrılmıştır. Son derece etkileyici bir üslupla yazılan bu şiirlerde vatan sevgisi, özlem, ayrılık, hüzün, hasret, aşk gibi çeşitli konular işlenmiş bazı şiirlerin altında şiiri yazan kadının kimliği ve yaşadığg yer açıkça belirtilirken bazılarında da yazanın isminin ve soy isminin ilk harfleri kullanılmıştır.

Derginin okur etkileşimine açık köşelerinden bir diğeri de Fizyonomi Tahlille$r i$ köşesidir. Kadın okurların dergiye yolladıkları fotoğraflarından hareketle onların özelliklerinin yorumlanıp analiz edildiği bölüme gönderilen fotoğraf sayısı dikkate alındığında (ortalama her dergide 7-8 adet) Fizyonomi Tahlilleri'nin kadınlar arasında ilgi gören köşelerden biri olduğu açıktır.

Ev Kadın dergisinin ilgiyle karşılandığını düşündüren bir diğer sürekli yazı dizisi de Gönül Ablaya Mektuplar bölümüdür. Okuyuculardan gelen soru ve sorunlara Gönül Abla imzası ile yanıt verilen bu köşede mektuplara yer verilmemiş, mektubu gönderene hitaben cevaplar ve tavsiyeler yazılmıştır. Kadınların bu bölümde dile getirdiği sorunların başında yaşadıkları duygusal meseleler, karşılıksız aşk, evlilikle ilgili problemler ve hayal kırıklıkları gelmektedir. Derginin bu köşesinde kadınlara verilen cevaplardaki anaç üslupta dikkat çekicidir. "Yavrucuğum, kızım, kardeşçiğim" gibi ifadelerin yer aldığı cevap yazılarında yeri geldiğine "Sevdiğiniz adamdan size hayır yok.", "Bir dakika değil, bir saniye bile kaybetmeden bu adamdan ayrtlın." gibi son derece keskin öneriler de bulunmaktadır. Ayrıca özellikle genç kızların gönül meseleleri ile sıkça cevap aradığı köşede kendi kızına tavsiye veren korumacı ve tecrübeli bir anne edası ile süslenmiş söylemlerde yer almaktadır:

“A yavrucuğum, insan hislerini, temayüllerini, düşüncelerini bu derece belli ederse, netice böyle olur tâbii... Erkekler çocuk gibidir. Fazla üstlerine düşüldü mü yüz bulup şımarırlar. Onlara herşeyi ancak yüzde on nisbetinde göstermek, belli etmek lâzımdır...”(1949-59: 25). 
Buna benzer yazılarda değişmez nitelendirilen, genellenen ve erkek doğasına dayandırılan meselelerin sabrederek üstesinden gelinebilecek sorunlar olduğu ifade edilirken aynı zamanda "Her kadının vazifesi ömrü boyunca hayatını erkeğini sevmeye devam etmek ve onun da kendisini sevmesini temin etmektir. Böyle kuvvetli bir sevgi ile kurulan ve devam eden yuvalar daima saadet ile doluyor." (1949-53: 18) şeklindeki söylemlerle kadına görevleri de hatırlatılmaktadır.

$\mathrm{Bu}$ örnekler ve konu başlıklarından da anlaşılacağı üzere Ev Kadın dergisinin hedef kitlesini büyük ölçüde ev kadınları oluşturmaktadır. Ev kadınlarının karşılaştığı düşünülen problemlere ve bu problemlere ilişkin çözüm önerileri ve tavsiyelere yer verilen dergide siyasi içeriklere, kadın hakları tartışmalarına rastlanmazken, eğitim konusu da çocuk eğitimine dair yazılan yine tavsiye niteliğindeki makalelerde ortaya konulmuştur. Erken Cumhuriyet döneminin ev kadınlığ ve annelikle yüceltilen kadın imajının spesifik olarak yansıtıldığı derginin modern kadın anlayışını ise büyük ölçüde dış görünüş, bakım ve davranış kalıpları ile sunduğu söylenebilir.

\section{Sonuç}

Osmanlı Devleti'nin son dönemlerinde hız kazanan modernleşme hareketlerinin hedef kitlelerinden biri kadınlardır. Kadın konusu özellikle II. Meşrutiyet'le beraber önemli bir gündem haline gelmiştir. Uzun yıllar ataerkil düzenin ve dini referansların şekillendirdiği Osmanlı Devleti'nde kadın söyleminin tartışmaya açılmasında XIX. yüzyılda yayınlanmaya başlayan kadın dergileri de etkili olmuştur. Özellikle kentli üst sınıf Osmanlı kadınları tarafindan merakla takip edilen bu yayınlarda bir taraftan kadın eğitimi, kadın hakları gibi meseleler gündeme taşınırken diğer taraftan da aile, evlilik, moda gibi konularda yazılan yazılar yer almıştır. Bu süreli yayınlar kadın konusundan hareketle yaşanılan toplumsal değişim ve dönüşümlerin görülmesi içinde önemli kaynaklardır.

Osmanlı Dönemi kadın dergileri yayınlandıkları sürede kadınların seslerini duyurmalarına ve kadın taleplerine yönelik kamuoyu oluşmasına da aracılık etmiştir. Başta erkek yazarların çoğunlukta olduğu bu yayınlarda zamanla kadın yazarların sayısı da artmış, kadınlar yazarlık dışında yazı işleri müdürlüğü gibi görevler aracılı$\breve{g} 1$ ile de dergilerde yer almaya başlamıştır. Dönemin kadınlarının başta eğitim olmak üzere kurumsal alanlara ilişkin taleplerini, şikâyetlerini duyurmanın bir yolu olarak gördükleri kadın dergileri aynı zamanda dönemin özgürlük havasının da izlerini taşımaktadır. Kendilerini bu dergiler aracılığı ile ifade etme fırsatı bulan Osmanlı kadını için modernleşme hareketleri tam anlamı ile sosyal ve ekonomik hayata katılım sağlamasa da kadının toplum içindeki konumu önemli ölçüde değişmiştir. Kadın eğitimini önemsiz ve gereksiz gören bir devlette kadınların yükseköğrenime dair talepleri tartış1lır hale gelmiştir. Söz konusu tartışmalara yön veren ve daha geniş kitlelere duyuran kadın dergilerindeki bu istekler dönemin aydınları tarafından da desteklenmiştir. 
Osmanlı Devleti'nin son döneminde kadın dergileri aracılığ ile de pekiştirilen eğitimli, çağdaş kadın imajı erken Cumhuriyet döneminin kadın politikalarına da yön vermiştir. Cumhuriyet rejimi pek çok ülkeden önce kadınlara seçme, seçilme gibi temel yurttaşlık haklarını tanırken, aynı zamanda kadını devletin temel aktörlerinden biri olarak konumlandırmıştır. Bu süreçte, çağdaş, laik bir toplum inşa etme arzusu kadar içinde bulunulan ekonomik koşulların da etkisi vardır. Cumhuriyet' in ilanı ile yeni kurulan devlerin öncelikleri arasında yer alan sağlıklı nesiller yetiştirme görevi önemli bir vazife olarak kadına verilmiştir. Temel hakları için mücadele etme gerekliliği olmayan Türk kadını eğitimli, çağdaş ve aydın kimliği ile bu görevi büyük ölçüde içselleştirmiştir. Dönemin kadın dergilerindeki kadın imajı da bu doğrultuda sunulan bir kadın profiline dayanmaktadır.

Erken Cumhuriyet dönemi kadın dergilerinde dış görünüşü ile batılı, eğitimi ile çağın koşullarına uyum sağlayabilen, üretken ama diğer taraftan da geleneksel rolleri içselleştirmiş ve bu rolleri yerine getirme kabiliyet ve becerisine sahip bir kadın anlayışı mevcuttur. Ev Kadın dergisi de bu anlayışa göre yayın yapan dönemin kadın dergilerinden biridir. 1945-1950 yılları arasında 64 sayı yayınlanan dergide çocuk bakımı, ev işleri, moda, güzellik gibi konular ön plana çıarken aynı zamanda diğer kadın dergilerinde olduğu gibi kadına öncelikli vazifesi olan annelik ve eş rolü hatırlatılmakta hatta bu vazifeyi daha iyi sürdürmesine yönelik önerilere de dergideki yazılarda sıkça yer verilmektedir. Ev Kadın dergisi evine gerekli özeni gösteren, sağlıklı ve gürbüz çocuklar yetiştiren ve bunların yanında kendi bakımına, görünüşüne dikkat eden kadın için bunun çeşitli yollarını sunan, hedef kitle olarak ev kadınlarına hitap eden bir dergidir. Erken Cumhuriyet dönemindeki kadın dergilerinin pek çoğunda olduğu gibi bu dergide de hararetli kadın hakları tartışmalarına, siyasi konularda yazılan yazılara yer verilmemiştir. Dergide kültürlü, bilgili ve üretken kadın imajı geleneksel rollerle harmanlanmış, iyi bir eş ve anne olarak kadından beklenen davranışların nasıl olması gerektiğinin üzerinde durulmuştur. Bu yönü ile Ev Kadın dergisi toplumdaki dönemin kadın anlayışının ve kadın imajının geleneksel cinsiyet rolleri bağlamında yansıtıldığı bir yayındır.

\section{Kaynakça}

Acun, F. (2007). Görsel verilerde kadın imajı (1923-1960). SDÜ Fen Edebiyat Fakültesi Sosyal Bilimler Dergisi, (16), 91-112.

Akagündüz, Ü. (2012). 1918-1928 yılları arasında kısa ömürlü Osmanlı'ca kadın dergileri hakkında bir değerlendirme. Kebikeç, (34), 323-346.

Akın, Y. (2004). Gürbüz ve yavuz evlatlar. Erken Cumhuriyet’te beden terbiyesi ve spor. İstanbul: İletişim.

Ateş, N. Y.(2009). Yeni harflerle kadın yolu/Türk kadın yolu (1925-1927). İstanbul: Kadın Eserleri Kütüphanesi Bilgi Merkezi Vakfi. 
Çakır, S. (1996). Osmanlı kadın hareketi. İstanbul: Metis.

Gelgeç, A. B. (2009). Cumhuriyet dönemi kadın imgesi üzerine bir değerlendirme. Ankara Üniversitesi Türk İnk1lap Tarihi Enstitüsü Atatürk Yolu Dergisi, (44), 627-638.

Kandiyoti, D. (1999). Modernin cinsiyeti: Türk modernleşme araştırmalarında eksik boyutlar, Türkiye'de Modernleşme ve Ulusal Kimlik (N. Elhüseyni, Çev.) (Sibel Bozdoğan, Reşat Kasaba Ed.) Ankara: Türk Tarih Vakfi Yurt, 99-117.

Kurnaz, Ş. (1991). Cumhuriyet öncesinde Türk kadını (1839-1923). Ankara: T.C. Başbakanlık Aile Araştırma Kurumu Başkanlığı.

Kurnaz, Ş. (1996). Millî mücadele döneminde cephede ve basında Türk kadını. Kastamonu'da ilk kadın mitinginin 75. yıldönümü uluslararası sempozyumu, Ankara: Atatürk Araştırma Merkezi, 58-68.

Lüküslü, D. (2009). Türkiye'de gençlik miti, 1980 sonrası Türkiye gençliği. İstanbul: İletişim.

Mutlu, N. (2009). Popüler kadın dergilerinde kadın temsili (Örnek olay: Cosmo-Politan Dergisi). yayınlanmamış,yüksek lisans tezi. Konya: Selçuk Üniversitesi Sosyal Bilimler Enstitüsü.

Özen, H. (1994). Tarihsel süreç içinde Türk kadın gazete ve dergileri (1868-1990). İstanbul: Graphis.

Peltekoğlu, F. B. (1995). Dergiciliğin gelişimi ve Türkiye'de kadın dergileri. Marmara İletişim Dergisi, (9), 113-139.

Saktanber, A. (1994). Türkiye'de medyada kadın: Serbest, müsait kadın veya iyi eş, fedakâr anne. 1980’ler Türkiye'sinde Kadın Bakış Açısından Kadınlar (Ş. Tekeli, Yay. Haz.) İstanbul: İletişim, 211-232.

Sancar, S. (2014). Türk modernleşmesinin cinsiyeti erkekler devlet kadınlar aile kurar. İstanbul: İletişim.

Şahin, E. (2018). Geçmişten günümüze kadın süreli yayınlarına karşılaştırmalı bir yaklaşım. Türk ve İslam Dünyası Sosyal Araştırmalar Dergisi, 5(16), 86-105.

Tekeli, Ş. (1982). Kadınlar ve siyasal toplumsal hayat. İstanbul: Birikim.

Tekeli, Ş. (1983). Kadın, Cumhuriyet dönemi Türkiye ansiklopedisi. (5), 1190-1204.

Vatter, S. (1998). Şam'ın militan tekstil dokumacıları: Ücretli zanaatkârlar ve Osmanlı işçi hareketleri. 1850-1914, Osmanlı'dan Cumhuriyet Türkiye'sine işçiler 1839-1950, Der. Donald Quataert ve Erik Jan Zürcher. İstanbul: İletişim.

\section{Süreli yayınlar}

Ana dergisi (1938-6).

Ev Kadın dergisi (1949-51, 1949-53, 1949- 56, 1949- 59).

Türk Kadını dergisi (1944-7, 1945-12, 1948-10). 


\section{Ekler}

Ev Kadın Dergisi Görselleri

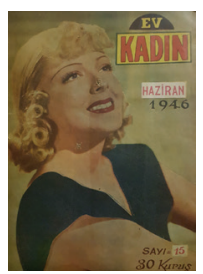

1-Ev Kadın dergisi kapak

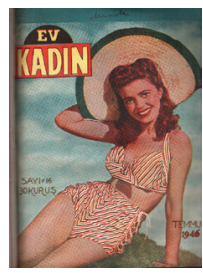

2-Ev Kadın dergisi kapak

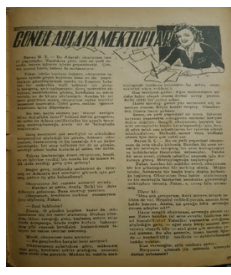

3-Güzin Ablaya Mektuplar

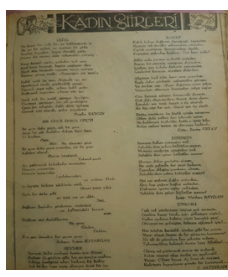

4- Kadın Şiirleri

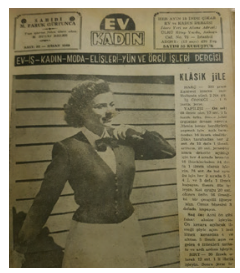

5-Ev Kadın dergisi iç sayfa örneği

\section{Ev Kadın Dergisi Görselleri}

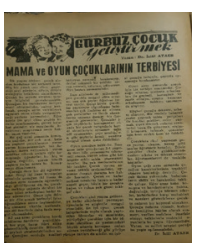

6- Ev Kadın dergisi- Gürbüz Çocuk Yetiștirmek

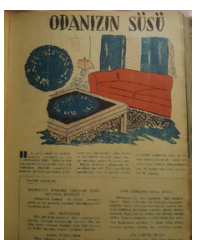

7- Ev Kadın dergisi Odanızın Süsü

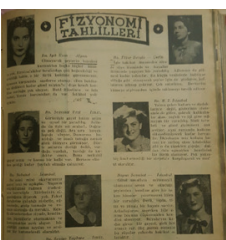

8- Ev Kadın dergisi - Fizyonomi Tahlilleri

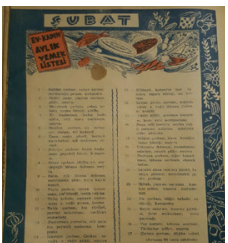

9- Ev Kadın dergisi-Yemek Listesi

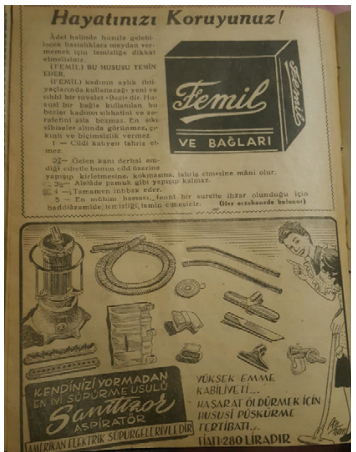

10- Ev Kadın dergisi reklam sayfası 